\title{
Varicella susceptibility in a Canadian population
}

\author{
Sam Ratnam PhD MPH SCM
}

S Ratnam. Varicella susceptibility in a Canadian population. Can J Infect Dis 2000;11(5):249-253.

OBJECTIVE: To determine susceptibility to varicella zoster virus (VZV) infection among children, pregnant women and health care workers in Newfoundland.

DESIGN: Cohort and cross-sectional, province-wide, population-based seroprevalence study.

STUDY POPULATION AND METHODS: A cohort of 586 children aged one year, a cross-sectional group of 1135 school children aged five to 15 years, 3643 pregnant women aged 15 to 45 years, and 5386 persons in health care settings aged 15 to 55 years. Susceptibility to varicella was determined by enzyme immunoassay based on serum antibody to VZV.

RESULTS: Among the cohort of 586 children, 565 (96.4\%) did not have detectable VZV antibody at one year of age. The proportion with VZV antibody increased thereafter to $12.8 \%$ and $33.9 \%$, respectively, at age two and four years, indicating the extent of exposure to VZV at these ages. Among the 1135 school-age children, the proportion testing positive for VZV antibody increased from $44 \%$ at five years of age to $88.9 \%$ at 15 years of age, indicating the cumulative incidence of varicella in this age group. Among pregnant women, $92.1 \%$ tested positive for VZV antibody, and the corresponding figure for the health care group was 93.1\%. In both groups, the proportion testing positive for VZV antibody increased with advancing age, from $89.6 \%$ for the 15 - to 19-year age group to $96.5 \%$ for those over the age of 40 years.

CONCLUSIONS: The risk of VZV infection increases steadily from one year of age, reaching a peak during school years. The study data support the recent Canadian recommendation to vaccinate any person older than 12 months of age who is susceptible to VZV. Among the adult population, the proportion susceptible will be under $10 \%$ for the foreseeable future, and for those at risk, selective vaccination based on their immune status would be a cost effective approach.

Key Words: Vaccination; Varicella; Varicella zoster virus; Immunity

\section{Sensibilité à la varicelle dans une population canadienne}

OBJECTIF : Déterminer la sensibilité au virus varicelle-zona (VZV) chez les enfants, les femmes enceintes et les travailleurs de la santé de la province de Terre-Neuve.

MODÈLE : Étude de séroprévalence basée dans la population, d'une cohorte et transversale et à l'échelle de la province.

POPULATION À L'ÉTUDE ET MÉTHODES : Une cohorte de 586 enfants d'un an, d'un groupe transversal de 1135 écoliers âgés de 5 à 15 ans, de 3643 femmes enceintes âgées de 15 à 45 ans, et de 5386 personnes du domaine de la santé âgées de 15 à 55 ans. La sensibilité à la varicelle a été déterminée par une technique immunoenzymatique basée sur la présence d'anticorps sériques contre le VZV.

RÉSULTATS : Dans la cohorte des 586 enfants, 565 (96,4 \%) n'avaient pas d'anticorps contre le VZV décelables à l'âge d'un an. La proportion d'entre eux porteurs d'anticorps décelables est ensuite passeé respectivement à 12,8 \% et à 33,9\%, à l'âge de deux ans et quatre ans, ce qui révélait l'étendue de l'exposition au VZV à ces âges. Parmi les 1135 écoliers, la proportion ayant un test positif pour le VZV est passeé de 44 \% à l'âge de cinq ans à 88,9\% à l'âge de 15 ans, indiquant l'incidence cumulative de la varicelle dans ce groupe d'âge. Chez les femmes enceintes, $92,1 \%$ avaient un test positif pour les anticorps anti-VZV, et le chiffre correspondant pour le groupe des travailleurs de la santé était de 93,1\%. Dans les deux groupes, la proportion ayant un test positif pour les anticorps contre le VZV a augmenté avec l'âge, passant de 89,6\% dans la tranche d'âge des 15 à 19 ans à 96,5\% dans celle des plus de 40 ans.

CONCLUSIONS : Le risque d'être infecté par le VZV augmente graduellement à partir de l'âge d'un an pour culminer chez les enfants d'âge scolaire. Les données de cette étude étayent la recommandation canadienne récente de vacciner toute personne de plus de 12 mois sensible au VZV. Dans la population adulte, la proportion sensible sera inférieure à $10 \%$ dans un avenir prévisible, et pour les individus à risque, une vaccination sélective basée sur leur état immunitaire serait une approche rentable.

\footnotetext{
Newfoundland Public Health Laboratory, Department of Health and Community Services, and Division of Community Health, Faculty of Medicine, Memorial University of Newfoundland, St John's, Newfoundland

Correspondence and reprints: Dr S Ratnam, PO Box 8800, Newfoundland Public Health Laboratory, St John's, Newfoundland A1B 372. Telephone 709-737-6568, fax 709-737-7070, e-mail nphlab@newcomm.net

Received for publication July 12, 1999. Accepted October 26, 1999
} 
A lthough varicella is a self-limiting disease in preschool and school-aged children, the risk of complications and hospitalizations following varicella in healthy children may be higher than reported a decade ago (1). Also, reports from the United States and the United Kingdom have indicated an upward shift in the age distribution of varicella (2-4). This shift has major public health implications because varicella is generally more severe in adolescents and adults, and can result in severe life-threatening complications and death in previously healthy individuals (5-9). Varicella also has important consequences for susceptible, pregnant women (3). Varicella during pregnancy can lead to congenital varicella syndrome in the fetus, and perinatal exposure can result in severe neonatal varicella with a fatality rate of as much as $20 \%$ (10). Nosocomial varicella can be both costly to the hospital and disruptive to patient care, and susceptible health care workers play a major role in transmitting the disease in this setting (11-13). Regardless of a person's age, varicella may be lethal in the presence of biological or iatrogenic immunosuppression. The continuing spread of HIV and the increasing number of individuals undergoing solid or nonsolid organ transplantation, along with the changing epidemiology of varicella, are expected to contribute to future varicella morbidity and mortality rates (5). The cost of varicella in Canada has been estimated to be $\$ 122.4$ million/annum or $\$ 353 /$ case (14).

Varivax, a live, attenuated varicella virus vaccine (Merck Frosst Canada and Company, Canada), was recently approved for routine use in Canada. The Canadian National Advisory Committee on Immunization has since recommended varicella vaccine to any person older than 12 months of age who is susceptible to varicella (14). Following licensing of Varivax in the United States in 1995, the United States Advisory Committee on Immunization Practices made a similar recommendation (6). Varicella immunity is desirable in adolescents and adults, and there are indications for assessing varicella immune status for specific populations from the standpoint of vaccination and other preventive strategies $(6,12-14)$. In view of the above, and because there is no current information on the prevailing susceptibility to varicella zoster virus (VZV) in the Canadian population, a study was carried out to assess the prevalence of VZV antibody among groups of people representative of the general population in Newfoundland.

\section{STUDY POPULATION AND METHODS}

The provincial Public Health Laboratory (PHL) in St John's, Newfoundland had access to serum samples previously collected from preschool and school-aged children across the province for a related study. These specimens were used to determine varicella susceptibility in children of different age groups in Newfoundland. Routine seroscreening services for infectious diseases including varicella are centralized at the PHL, and these services are used for prenatal screening as well as for pre-employment and student pre-admission screenings. The above provided the PHL with access to serum specimens from different age groups of adults representing the general population in the province.

Study population: The study population was from across the province, and was divided into the following four groups: preschool children; school-aged children; pregnant women; and persons in health care settings. The preschool group was a cohort of 586 children aged one year, 288 females and 298 males, representing all five health regions in the province. They were randomly enrolled over a one-year period during 1992 and 1993 in a study dealing with measles immunization strategy. In connection with this study, blood samples were obtained from this cohort at one, two and four years of age, and the leftover serum specimens were used in the present study.

The school-aged group comprised 1135 children, five to 15 years of age. They were enrolled during 1995 in a crosssectional study also dealing with the measles immunization strategy. The number of children in each age group ranged from 50 (five years old) to 150 (11 years old), and both sexes were equally represented. To obtain provincial representation, these children were enrolled through random selection of schools across the province. A two-stage cluster sampling was completed in each of five health regions in the province; three schools were picked at random in each health region, and up to four classes within each grade in a school were approached to enrol volunteers.

The pregnant women group comprised 3643 women, 15 to 45 years of age. The number of women in each of five-year age group ranged from 268 (age 15 to 19 years) to 1139 (age 25 to 29 years), with the exception of the 40 - to 45 -year age group, which contained 57 women; $81 \%$ were in the 20 - to 34 -year age group. This group comprised slightly over one-half of those women who had their routine prenatal screening performed in the province during 1997. They were included in the study based on the availability of their leftover serum specimens.

The group in health care settings comprised 5386 persons, 15 to 55 years of age. The number of persons in each of fiveyear age group ranged from 411 (age 45 to 49 years) to 1284 (age 20 to 24 years), with the exception of the 50- to 55-year age group, which contained 62 persons. This group represented those whose blood specimens were received for hepatitis B, measles, rubella and/or varicella immune status screening as part of their routine health check during 1997. The majority in this group were health care workers representing various medical institutions across the province, and the rest were those seeking admission into professional schools in health care settings.

With the exception of pre-employment and pre-admission varicella immune status screenings which were performed nominally on request, this study was conducted as an anonymous population-based investigation using unidentified leftover specimens. The information retained on the study subjects included the age and sex of the patient. This study was approved by the Human Investigation Committee, Faculty of Medicine, Memorial University of Newfoundland, St John's, Newfoundland.

Laboratory method: Varicella immunoglobulin (Ig) G ELISA test (Clark Laboratories Inc, USA) was used to determine VZV antibody status. This test allows for quantitation of varicella antibody and expression of the same in international units 


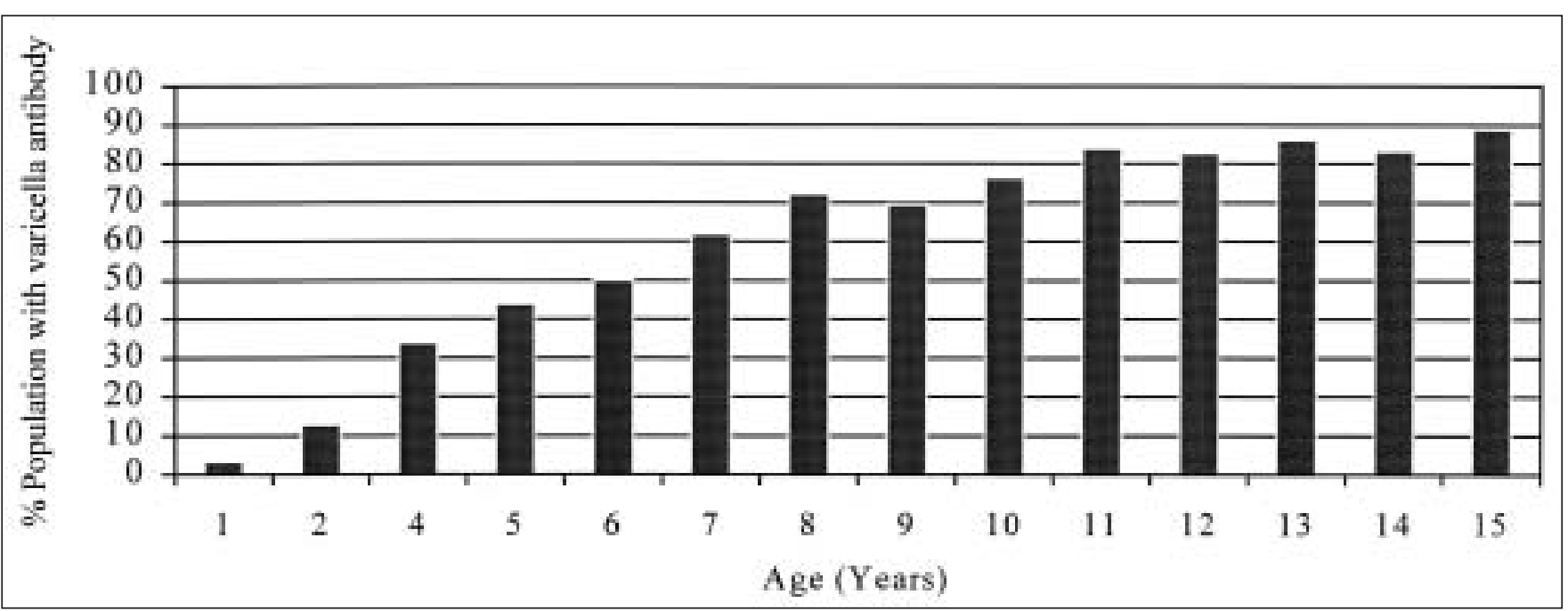

Figure 1) Age-specific prevalence of antibody to varicella zoster virus in a population from Newfoundland. Based on a total of 1721 children and includes a cohort of 586 children who were tested at one, two and four years of age, and a cross-sectional group of 1135 children five to 15 years of age

(IU). By this test, a reading of less than 0.14 IU indicated nonimmunity, 0.14 to $0.18 \mathrm{IU}$ was an equivocal result, and greater than $0.18 \mathrm{IU}$ indicated immunity. In comparison with the immunofluorescent technique, this test has shown to have a relative sensitivity of $99.4 \%$ and specificity of $97 \%$ (package insert, Clark Laboratories). The Clark assay was found to be comparable with the Behring Enzygnost anti-VZV/IgG (Dade Behring, Germany) assay in a prestudy in-house evaluation. This test was performed according to the instructions provided by the manufacturer, and specimens with equivocal test results were considered to be negative for VZV antibody for analysis purposes.

\section{RESULTS}

Among the cohort of 586 preschool children, 565 (96.4\%) did not have detectable VZV antibody, and two (0.3\%) had equivocal results at one year of age. The proportion testing positive for VZV antibody increased from 3.2\% at one year of age to $12.8 \%$ and $33.9 \%$, respectively, at two and four years of age, indicating the extent of natural VZV exposure of the cohort during these intervals. The cross-sectional study of 1135 school children indicated a steady increase in the proportion testing positive for VZV antibody, from $44 \%$ at five years to $88.9 \%$ at 15 years of age, again indicating the cumulative incidence of varicella with advancing age. The above data on the age-specific prevalence of antibody to VZV for these two groups of children are shown in Figure 1. Among the 3643 pregnant women screened, $3354(92.1 \%)$ tested positive for VZV antibody. Similarly, among the 5386 persons in health care settings, 5013 (93.1\%) tested positive for VZV antibody. In both groups, the proportion testing positive for the antibody showed an upward trend with advancing age, ie, $89.6 \%$, age 15 to 19 years; $93.2 \%$, age 25 to 29 years; and $96.5 \%$, older than age 40 years, etc. Throughout the study, those testing positive for varicella antibody mostly had titres greater than $4 \mathrm{IU} / \mathrm{mL}$.

\section{DISCUSSION}

A few population-based studies have been conducted elsewhere to determine varicella susceptibility and age-specific incidence of varicella (15-19). The present study was based on a total population of 10,750 persons, comprising four groups of people covering the age range of one to 55 years. This sample size represented the general Newfoundland provincial population of approximately 680,000 people. This was a large scale seroprevalence survey, and it has provided current data on varicella susceptibility for a representative Canadian population. The data obtained in this study are consistent with those reported for similar populations elsewhere (15-19). The presence of VZV-specific antibody in the absence of acute VZV infection is indicative of immunity to varicella, and therefore, testing for VZV antibody has been a traditional method for the assessment of varicella immune status. However, because the cellular immunity plays an important role in protection against varicella, the absence of VZV antibodies may not necessarily imply susceptibility. On the other hand, and more importantly, not all persons with VZV antibody are immune to varicella because reinfection can occur in those with a prior history of varicella (20-22). The present study was a population-based survey carried out to determine the prevailing levels of susceptibility from the standpoint of varicella vaccination strategy, and therefore, the absence of VZV antibody was used as a marker of no prior exposure to varicella and, hence, taken to indicate susceptibility. For the same reason, those testing equivocal for the VZV antibodies by the assay used in the study were also considered susceptible.

The study data indicated that, among one-year-old children, including those with equivocal results, the proportion susceptible was $96.8 \%$. Because the study showed that $92.1 \%$ of pregnant women had varicella antibody, it can be assumed that most children would have been born with maternally acquired varicella antibody, but obviously this antibody wanes to undetectable levels within a year in the majority of children. 
The small proportion testing positive for varicella antibody at this point may represent those with the residual maternally acquired antibody and/or those already exposed to VZV. Regardless, these data indicate that the risk of infection to varicella, if any, is minimal before one year of age. This risk increases considerably after this age, both during the preschool and early school years, as shown by a steady increase in the proportion of children testing positive for VZV antibody (Figure 1). It is worth noting that part of the above data were generated in a cohort of one-year-old children who were followed up over a three-year period. The study data correlated with Newfoundland provincial disease surveillance data, which indicate that, over the past two decades, $70 \%$ to $85 \%$ of reported cases of varicella were in the five- to 10-year age group (23). It is also significant that the data generated in this study based on VZV antibody status of Newfoundland children correlate very well with the data reported in two other Canadian studies involving Manitoba and Quebec children, both of which were obtained via caregiver questionnaires $(14,24,25)$. With the availability of an effective varicella vaccine, universal varicella immunization is now considered important for all children $(6,12,14)$. In this context, the above data clearly support both the Canadian and the American recommendations to vaccinate routinely all susceptible children at 12 to 18 months of age $(6,14)$.

Varicella occurring during pregnancy is a growing clinical and public health concern $(6,10)$. In 1997, a total of approximately 6500 women underwent routine prenatal screening in the province, and this was estimated to represent over $90 \%$ of pregnancies that occurred in Newfoundland during that year; the study population of 3643 well represented this group. The study indicated that the proportion of women testing susceptible was under $10 \%$, and this falls within the range reported for general populations elsewhere (26). In the absence of a vaccination program, it is likely that there will be a greater accumulation of susceptible women of childbearing age if there is an upward shift in the age distribution of varicella as indicated in British and American populations (2-4). It is worth noting that there is a trend of increasing rubella susceptibility among women of childbearing age in Canada who received a single dose of measles-mumps-rubella vaccine during the $1970 \mathrm{~s}$ (27). In this context, it appears that a changing epidemiology of varicella could lead to a similar trend in VZV susceptibility. However, this proportion will remain small in the foreseeable future. Varicella vaccination is recommended for susceptible women of childbearing age $(6,12)$. As a positive history of varicella is highly predictive of varicella immunity (15), it will be cost effective to screen those with a negative or uncertain history of varicella, and selectively vaccinate those who are found susceptible. From this standpoint, it may be desirable and practical to include varicella immune status testing, if indicated, in the routine work-up of prenatal screening. Such a selective screening approach will undoubtedly provide the opportunity to identify susceptible women and facilitate vaccination after delivery, a strategy similar to that of the current prenatal rubella screening and vaccination program.

Introduction of varicella into the hospital environment commonly occurs, and nosocomial varicella is a major economic and health concern. Varicella in immunocompromised patients can result in severe and sometimes fatal illness. Preemployment screening of all hospital workers for varicella susceptibility or selective screening of those with a negative varicella history has been recommended $(13,28)$. With the availability of an effective varicella vaccine, it will be prudent to implement such an approach and selectively immunize those found susceptible. Even without the availability of a varicella vaccine, varicella screening of health care workers who have direct patient contact is a routine practice in many centres, and has been so in Newfoundland for many years. In the present study, $6.9 \%$ tested susceptible, and this is similar to the figures reported for health care workers in the United States (29). The proportion susceptible among those in health care settings in Canada is likely to be well below 10\%, and selective screening and vaccination will be a cost effective approach in this setting (29).

Varicella is of major public health significance, and cost effectiveness studies have indicated considerable economic and health benefits with routine varicella vaccination of children (30-32). Chickenpox is now the leading cause of vaccinepreventable deaths among immunocompromised children, and varicella in adults and varicella complications may be more frequent than previously estimated (1,7-9). Although less than $5 \%$ of varicella cases are reported among adults over 20 years of age, $55 \%$ of varicella-related deaths occur in this age group (7). In addition, herpes zoster is also a public health and social concern, especially with increasing life spans $(5,33)$. These facts underscore the public health and economic consequences of varicella and the need to implement an effective nationwide varicella immunization program.

\section{REFERENCES}

1. Choo PW, Donahue JG, Manson JE, Platt R. The epidemiology of varicella and its complications. J Infect Dis 1995;172:706-12.

2. Gray GC, Palinkas LA, Kelley PW. Increasing incidence of varicella hospitalizations in United States army and navy personnel: Are today's teenagers more susceptible? Should recruits be vaccinated? Pediatrics 1990;86:867-73.

3. Fairley CK, Miller E. Varicella-zoster virus epidemiology A changing scene? J Infect Dis 1996;174(Suppl 3):S314-9.

4. Miller E, Vurdien J, Farrington P. Shift in age in chicken pox. Lancet 1993;341:308-9.

5. Weller TH. Varicella: Historical perspective and clinical overview. J Infect Dis 1996;174(Suppl 3):S306-9.

6. Prevention of varicella: Recommendations of the Advisory Committee on Immunization Practices (ACIP). Centers for Disease Control and Prevention. MMWR Morb Mortal Wkly Rep 1996;45(RR-11):1-36.

7. Varicella-related deaths among adults - United States, 1997. MMWR Morb Mortal Wkly Rep 1997;46:409-12.

8. Varicella-related deaths among children - United States, 1997. MMWR Morb Mortal Wkly Rep 1998;47:365-8.

9. Varicella-related deaths - Florida, 1998. MMWR Morb Mortal Wkly Rep 1999;48:379-81.

10. Grant A. Varicella infection and toxoplasmosis in pregnancy. J Perinat Neonatal Nurs 1996;10:17-29.

11. Hyams PJ, Stuewe MCS, Heitzer V. Herpes zoster causing varicella (chickenpox) in hospital employees: Cost of a casual attitude. Am J Infect Control 1984;12:2-5.

12. Holmes SJ. Review of recommendations of the Advisory Committee on Immunization Practices, Centers for Disease Control and Prevention, on varicella vaccine. J Infect Dis 1996;174(Suppl 3):S342-4. 
13. Casto DT. Varicella vaccination of health care workers. Am J Health Syst Pharm 1996;53:2628-35.

14. Health Canada. Statement on recommended use of varicella virus vaccine. Can Commun Dis Rep 1999;25:1-16.

15. Lieu TA, Black SB, Takahashi H, et al. Varicella serology among school age children with a negative or uncertain history of chickenpox. Pediatr Infect Dis J 1998;17:120-5.

16. Kilgore PE, Kruszon-Moran D, van Loon FPL, et al. Seroprevalence of antibody to varicella in a population-based survey. 37th Interscience Conference on Antimicrobial Agents and Chemotherapy. Toronto, September 28 to October 1, 1997. (Abst)

17. Gil A, Gonzalez A, Dal-Re R, Ortega P, Dominguez V. Prevalence of antibodies against varicella zoster, herpes simplex (types 1 and 2), hepatitis B and hepatitis A viruses among Spanish adolescents. J Infect 1998;36:53-6.

18. Struewing JP, Hyams KC, Tueller JE, et al. The risk of measles, mumps and varicella among young adults: A serosurvey of US Navy and Marine Corps recruits. Am J Public Health 1993;83:1717-20.

19. Finger R, Hughes JP, Meade BJ, Pelletier AR, Palmer CT. Agespecific incidence of chickenpox. Public Health Rep 1994;109:750-5

20. Iltis JP, Castellano GA, Gerber P, Le C, Vujcic LK, Quinnan GV Jr. Comparison of the Raji cell line fluorescent antibody to membrane antigen test and the enzyme-linked immunosorbent assay for determination of immunity to varicella-zoster virus. J Clin Microbiol 1982;16:878-84.

21. Arvin AM, Koropchak CM, Wittek AE. Immunologic evidence of reinfection with varicella-zoster virus. J Infect Dis 1983;148:200-5

22. Gershon AA, Steinbert SP. Persistence of immunity to varicella in children with leukemia immunized with live attenuated varicella vaccine. $\mathrm{N}$ Engl J Med 1989;320:892-7.
23. Communicable Disease Report, Newfoundland Department of Health and Social Services.

24. Law BJ, Brownell MD, Walld R, et al. Chickenpox in Manitoba: A population-based assessment using the Manitoba Health Services Commission Database. 3rd National Immunization Conference, Calgary, December 6-9, 1998.

25. Boulianne N, Duval B, De Serres G, et al. History of varicella in children aged 8 to 10 years old and the perception of their patients of the usefulness of the varicella vaccine. 3rd National Immunization Conference. Calgary, December 6-9, 1998.

26. Wharton M. The epidemiology of varicella-zoster virus infections. Infect Dis Clin North Am 1996;10:571-81.

27. Ratnam S, West R, Gadag V, Williams B, Oates E. Rubella antibody levels in school-aged children in Newfoundland: Implications for a two-dose rubella vaccination strategy. Can J Infect Dis 1997;8:85-8.

28. Weitekamp MR, Schan P, Aber RC. An algorithm for the control of nosocomial varicella-zoster virus infection. Am J Infect Control 1985;13:193-8.

29. Tennenberg AM, Brassard JE, Van Lieu J, Drusin LM. Varicella vaccination for health care workers at a university hospital: An analysis of costs and benefits. Infect Control Hosp Epidemiol 1997;18:405-11.

30. Bentsi-Enchill A. Varicella-zoster virus disease and epidemiology: Seeking better control strategies - Part I. Can Commun Dis Rep 1998;24:193-8.

31. Lieu TA, Cochi SL, Black SB, et al. Cost-effectiveness of a routine varicella vaccination program for US children. JAMA 1994;271:375-81.

32. Huse DM, Meissner HC, Lacey MJ, Oster G. Childhood vaccination against chickenpox: An analysis of benefits and costs. J Pediatr 1994:124:869-74.

33. Arvin AM. Varicella-zoster virus: overview and clinical manifestations. Semin Dermatol 1996;15(Suppl 1):4-7. 


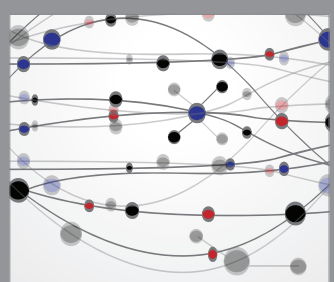

The Scientific World Journal
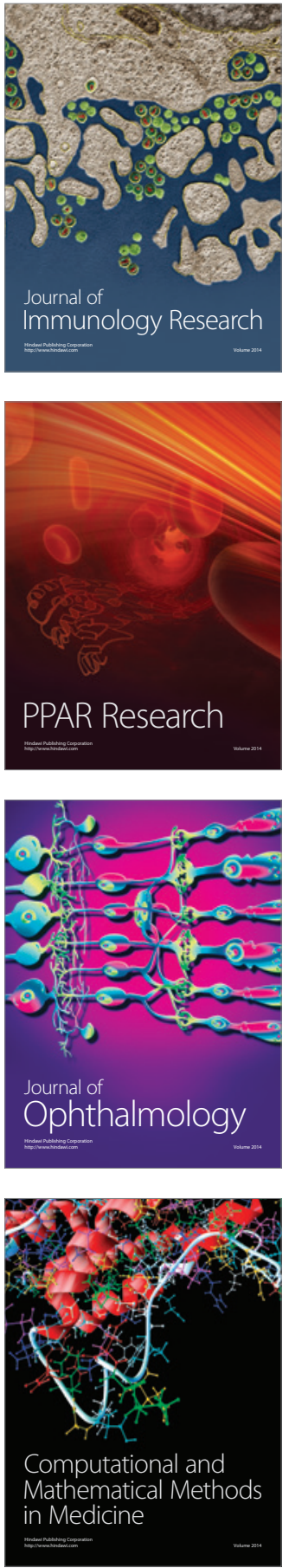

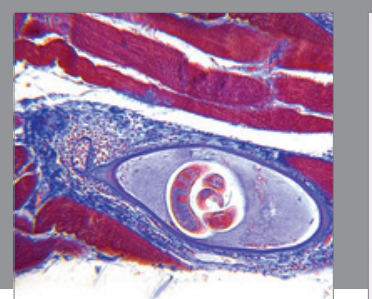

Gastroenterology Research and Practice

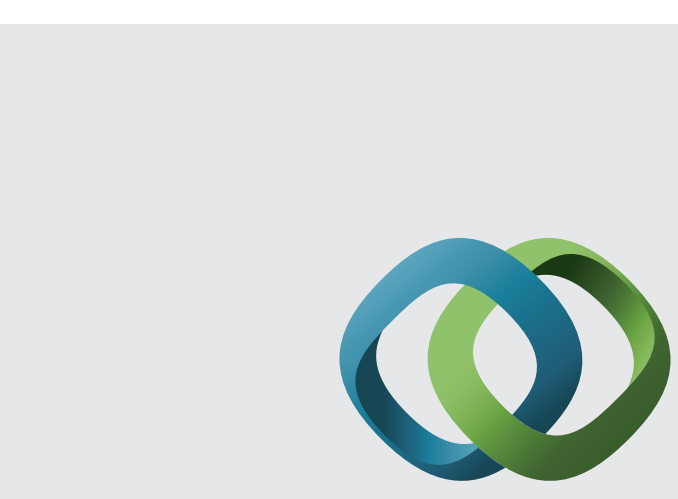

\section{Hindawi}

Submit your manuscripts at

http://www.hindawi.com
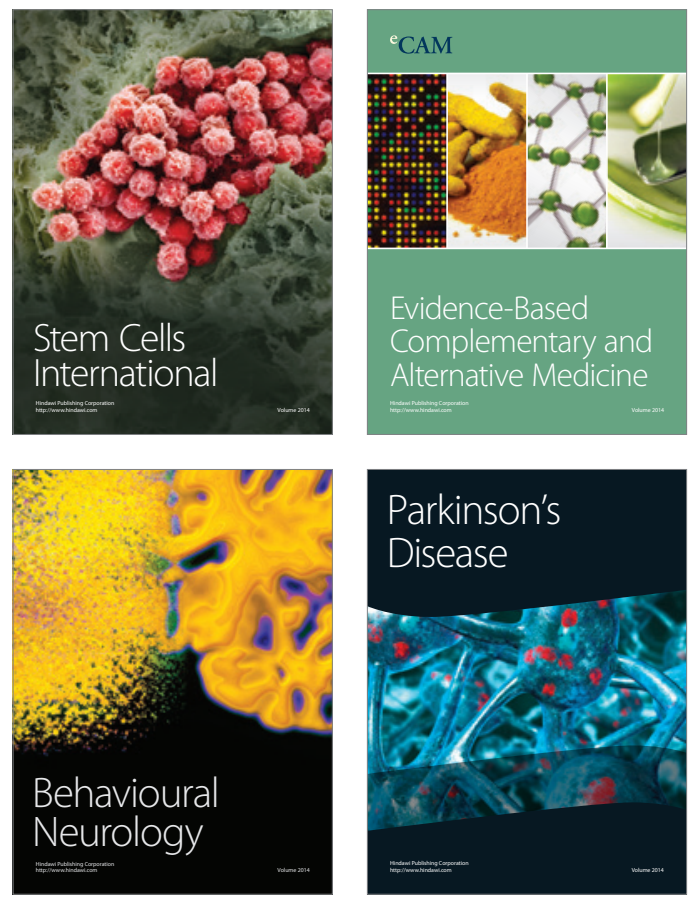
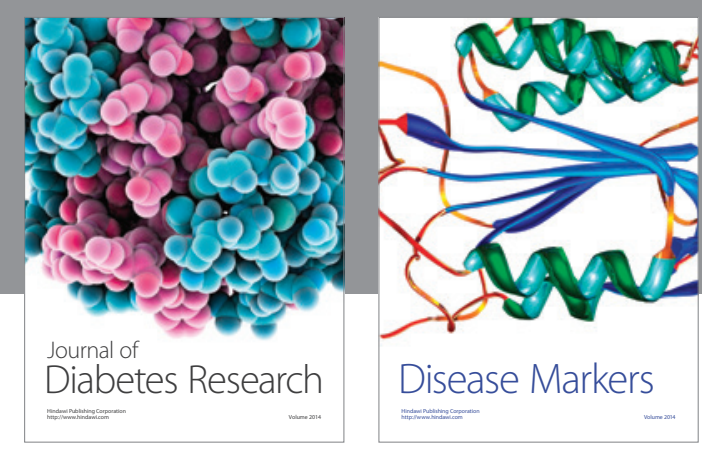

Disease Markers
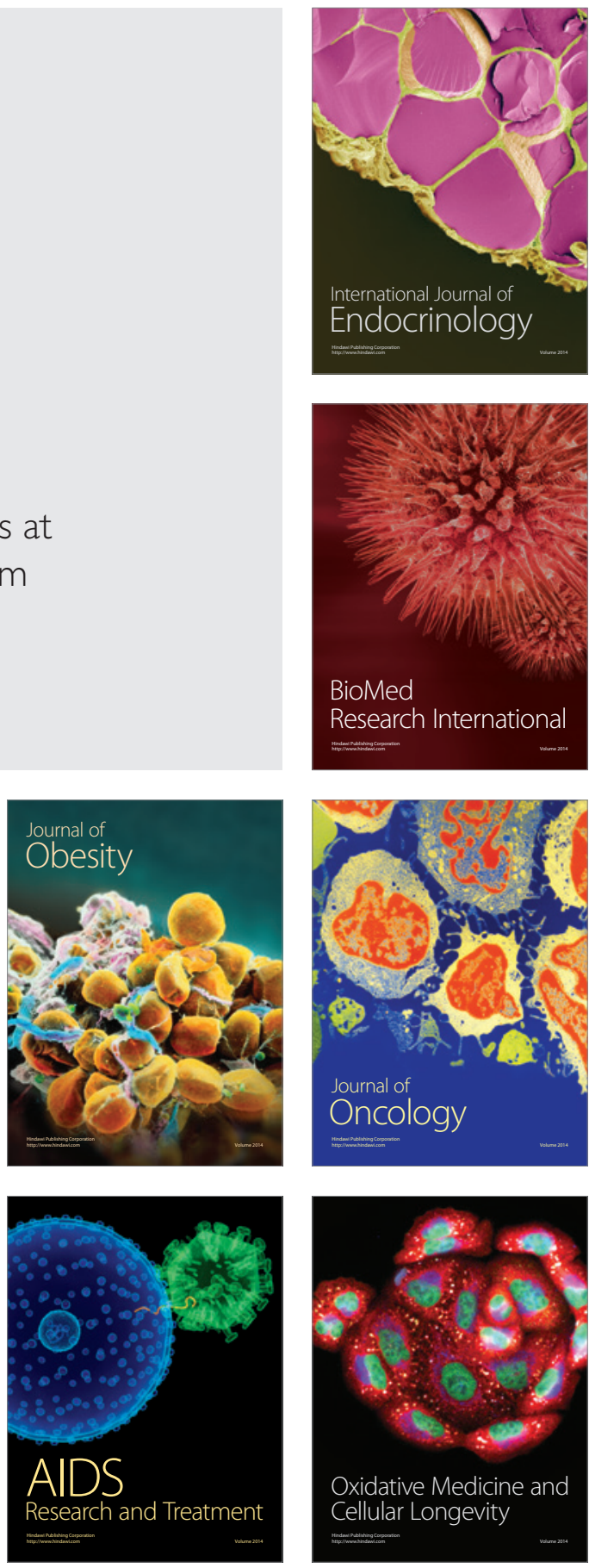